\title{
Respon dan Pemahaman Tukang Becak terhadap Pelatihan Bahasa Inggris yang Dilaksanakan Pemkab Banyuwangi dalam Menunjang Keberhasilan Wisata
}

\author{
(Pedicab Driver Response and Understanding of the English Language \\ Training Conducted in Banyuwangi District Government in Supporting the \\ Success of the Tour)
}

\author{
Siti Fatimah, Mohamad Dimyati ${ }^{1}$, Hari Sukarno \\ Jurusan Manajemen, Fakultas Ekonomi, Universitas Jember (UNEJ) \\ Jln. Kalimantan 37, Jember 68121 \\ E-mail:mysita92@gmail.com
}

\begin{abstract}
Abstrak
Tujuan penelitian ini adalah untuk memahami respon dan pemahaman tukang becak tentang pelatihan Bahasa Inggris yang dilaksanakan Pemkab Banyuwangi dalam menunjang keberhasilan wisata. Jenis penelitian ini adalah penelitian kualitatif. Subyek penelitian terdiri dari kelompok sosial yaitu seluruh tukang becak di kota Banyuwangi yang berperan serta dengan adanya pelatihan Bahasa Inggris. Informa penelitian ditenntukan dengan metode purposive. Metode analisis data dilakukan melalui empat langkah yaitu pengumpulan data, reduksi data, penyajian data, dan penarikan kesimpulan. Hasil penelitian menujukkan bahwa: 1) Respon tukang becak terhadap pelatihan Bahasa Inggris adalah mereka merasa mendapatkan manfaat untuk meningkatkan penghasilan dan manfaanya tidak hanya untuk sekarang tetapi juga untuk masa depan. Ada juga yang menyuruh putranya yang mengikuti pelatihan dan manfaatnya akan dirasakan oleh putranya tersebut, karena beranggapan bahwa jika mengikuti pelatihan akan mengurangi penghasilan mereka, hal ini karena hanya melihat jangka pendek. 2) tukang becak mendapatkan manfaat dapat mengenalkan tempat wisata yang ada di Banyuwangi kepada wisatawan asing, memberikan kemampuan tukang becak dalam berkomunikasi menggunakan Bahasa Inggris akan berpengaruh terhadap kenyamanan wisatawan asing yang datang berkunjung ke Kota Banyuwangi.
\end{abstract}

Kata Kunci: pemahaman, pelatihan bahasa inggris, respon, tukang becak.

\begin{abstract}
Research purposes is to understand the response and understanding of artisan rickshaw about training English carried out the district government Banyuwangi in supporting the success of tourist. Types of research used in this study is the qualitative research. Analyctal methods data in this study includes four seps that data collection, data reduction, data presentation, and conclusion. The conclusion of this research is 1) response artisan rickshaw to the training English language is the artisan rickshaw benefit many of training English especially the following the training to increase income and benfits not only to now but also for the future.there is also told his son who take the training and benefits will be felt by his son is, in this case artisan rickshaw that told his son who take training assume that will reduce income when taking part training this is because only see the short term.2) understanding of artisan rickshaw to the training English language is the artisan rickshaw to introduce the tourist attractions that is in Banyuwangi to the foreign tourists, understand the tourists foreign what kind, interact and communicate with foreign tourists, familiar with foreign cultures such as what, attract foreign tourists visiting in the city Banyuwangi, artisan rickshaw been able to understand the meaning of greeting the tourists, and become builders rickshaw tourism awareness. Income derived from the tourist is very different from the local people. So that the ability of artisan rickshaw in communicate using the English language will affect the comfort of foreign tourists visiting to the city Banyuwangi.
\end{abstract}

Keywords: comprehension, english language training, response, pedicab driver.

\section{Pendahuluan}

Pelatihan Bahasa Inggris bagi tukang becak yang dilakukan oleh Pemkab Banyuwangi dalam peningkatan wisatawan domestik maupun asing menimbulkan respon dan pemahaman dari tukang becak. Cara orang menerima dengan indera dan respon yang ditimbulkan berbeda-beda karena respon. Definisi respon adalah respon dapat diartikan sebagai suatu tanggapan, reaksi dan jawaban. Respon positif muncul karena ada yang terus mengikuti pelatihan Bahasa Inggris sampai merasakan manfaatnya dari mengikuti pelatihan tersebut. Respon negatif muncul karena ada sebagian tukang becak yang hanya mengikuti pelatihan Bahasa Inggris satu dan dua kali pertemuan saja dengan alasan kalau mengikuti terus pelatihan tersebut maka penghasilan untuk hari ini akan berkurang. Maka hanya sebagian tukang becak saja yang mengikuti pelatihan Bahasa Inggris tersebut. Terdapat beberapa faktor yang membuat beberapa tukang becak merasa tidak melanjutkan pelatihan Bahasa Inggris tersebut. Definisi Pemahaman adalah mencakup kemampuan untuk menangkap makna dan arti dari bahan yang dipelajari. Pemahaman tukang becak terkait dengan adanya pelatihan Bahasa Inggris sebagian ada yang paham dan tidak paham. Bupati Banyuwangi Abdullah Azwar Anas mengakui bahwa keberadaan tukang becak di daeahnya patut juga diperhatikan

1 Corresponding Author 
untuk menunjang pariwisata yang sedang menggelait. Sehingga perlu adanya motivasi untuk para tukang becak yang kurang memahami dan memaknai dari program ini.

Focus penelitian ini adalah: (1) Bagaimanakah respon tukang becak terhadap pelatihan Bahasa Inggris yang dilaksanakan Pemkab Banyuwangi dalam menunjang keberhasilan wisata, (2) Bagaimana pemahaman tukang becak tentang pentingnya pelatihan Bahasa Inggris yang dilaksanakan Pemkab Banyuwangi dalam menunjang keberhasilan wisata.

Penelitian ini bertujuan untuk: (1) Memahami respon tukang becak terhadap pelatihan Bahasa Inggris yang dilaksanakan Pemkab Banyuwangi dalam menunjang keberhasilan wisata, (2) Mengetahui secara mendalam pemahaman tukang becak terhadap pelatihan Bahasa Inggris yang dilaksanakan Pemkab Banyuwangi dalam menunjang keberhasilan wisata.

\section{Metode}

\section{Rancangan dan Desain Penelitian}

Rancangan penelitian menggunakan rancangan penelitian kualitatif dengan metode fenomenalogi. Penelitian kualitatif ini terjadi karena adanya perubahan paradigma dalam memandang suatu fenomena atau gejala. Paradigma dalam penelitian ini realitas sosial dipandang sebagai sesuatu yang holistik/utuh, komplek, dinamis dan penuh makna. Muhthar (2013:10) menyatakan bahwa penelitian kualitatif berusaha mendeskripsikan seluruh gejala atau keadaan gejala menurut apa adanya pada saat penelitian dilakukan.

\section{Jenis dan Sumber Data}

Penelitian ini menggunakan data primer yang diperoleh dari wawancara dan data sekunder yang diperoleh melalui catatan atau dokumen di Pemda Banuwangi terkait pelatihan bahasa Inggris bagi tukang becak.

\section{Subyek Penelitian}

\section{Kelompok Sosial}

Kelompok sosial dalam penelitian adalah seluruh tukang becak di kota Banyuwangi yang berperan serta dengan adanya pelatihan Bahasa Inggris. Informan penelitian ditentukan dengan metode purposive dengan kriteria: (1) Masyarakat Banyuwangi yang berprofesi sebagai tukang becak berlokasi Pasar Banyuwangi, Taman Sritanjung, Taman Blambangan. (2) Keluarga dari tukang becak tersebut. (3) Tentor Bahasa Inggris yang memberikan pelatihan. (4) Pemkab Banyuwangi (Dinas Pariwisata dan Kebudayaan).

\section{Informan}

Jumlah informan sebanyak 22 informan yang berhasil di wawancarai oleh peneliti adalah Tukang becak: Suhariyanto, Suhairi, Harli, Djamari, Indra, Jayadi, Budi, Anam, Hendra, Iman. Keluarga: Hasan, Tatik, Dika, Jamila, Dwi, Komariah, Sinta, Titik, Sri, Endang. Tentor: Sibon. Dinas Pariwisata dan Kebudayaan: Dariharto.

\section{Motode Analisis Data}

Aktivitas dalam analisis data kualitatif dilakukan secara interaktif dan berlangsung secara terus-menerus sampai tuntas sehingga datanya sudah jenuh atau tidak ada hal baru lagi (Miles dan Hubermen dalam Sugiyono, 2014:87). Analisis data dalam penelitian kualitatif dilakukan pada saat penupulan data berlangsung dan setelah pengumpulan data dalam periode tertentu (Sugiyono, 2014:91), teknik analisis data pada penelitian ini terbagi menjadi 4 (empat) tahap yaitu:

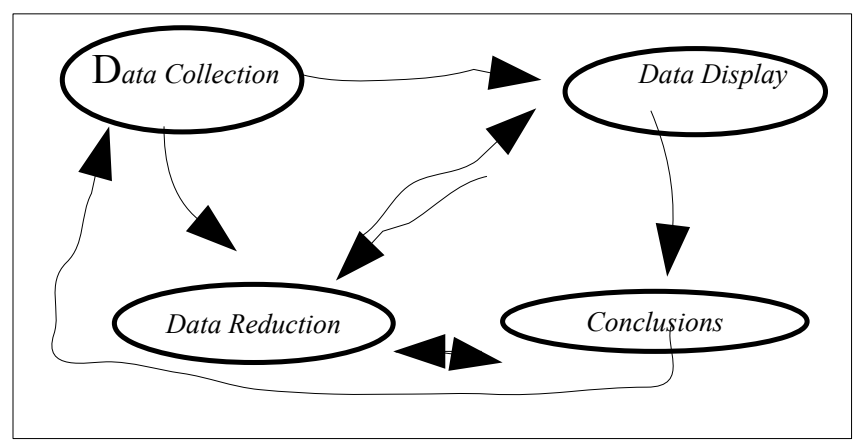

Sumber: Miles dan Huberman dalam Sugiyono (2014:92) Gambar 1. Komponen dalam Analisis Data (Interactive model)

\section{Hasil dan Pembahasan}

\section{Hasil}

Proses pengumpulan data menggunakan teknik wawancara dan dokumentasi. Kegiatan pertama mencari informan yang sesuai dengan kriteria informan yang telah ditetapkan. Setelah melalukan pengumpulan data, melakukan reduksi dari hasil data yang telah diperoleh, melalakukan display data dan kesimpulan.

\section{a. Pengumpulan Data (Data Collection)}

Informan berasal dari tukang becak. Proses wawancara dengan informan pertama yang dilakukan pada tanggal 30 Januari 2015 dengan Suhariyanto pukul 10.00 WIB, tempat wawancara di sekitar pasar Banyuwangi. Peneliti melakukan wawancara dengan menanyakan 5 pertanyaan yang telah disiapkan. Setelah proses wawancara selesai, selanjutnya melakukan dokmentasi penelitian. Informan kedua bernama Suhairi ditemui di sekitar pasar Banyuwangi, pada tanggal 21 Januari 2015 pukul 09.00 WIB. Ketika bertemu hal pertama yang dilakukan adalah melakukan penjelasan mengenai penelitian ini setelah itu melakukan proses wawancara dengan menanyakan 5 pertanyaan. Ketika proses wawancara, informan mampu menjawab dan bisa menggali informasi yang diinginkan. Pada saat wawancara dilakukan proses dokumentasi penelitian. Informan ketiga bernama Harli. Informan ketiga ditemui di sekitar pasar Banyuwangi pada tanggal 21 Januari 2015 pukul 11.00 WIB. Ketika proses wawancara, jawaban yang diberikan oleh informan sudah mampu memberikan informasi yang diinginkan. Pada saat proses wawancara berlangsung dilakukan sesi dokumentasi penelitian. Informan keempat bernama Djamari, wawancara dilakukan di sekitar pasar Banyuwangi pada tanggal 22 Januari 2015 pukul 10.00 WIB.

Proses wawancara dapat dilaksanakan dengan lancar karena informan mampu memahami maksud dari pertanyaan yang diberikan. Informan kelima bernama Indra, wawancara dilakukan di sekitar taman Blambangan. Pada tanggal 23 Januari 2015 pukul 09.00 WIB. Informan keenam bernama Jayadi. Informan ditemui pada tanggal 24 Januari 2015 pukul 09.00 WIB. Informan ketujuh bernama Budi dilakukan di sekitar taman Sritanjung pada tanggal 25 Januari 2015 pukul 10.00 WIB. Informan kedelapan bernama Anam ditemui pada 
tanggal 26 Januari 2015 pukul 11.00 WIB di sekitar taman Sritanjung. Informan kesembilan ditemui di sekitar pasar Banyuwangi bernama Hendra pada tanggal 27 Januari 2015 pukul 10.00 WIB. Informan kesepuluh ditemui pada tanggal 28 Januari 2015 pukul 10.00 WIB bernama Iman di sekitar pasar Banyuwangi. Pada proses wawancara informan mampu memberikan jawaban sesuai dengan pertanyaan yang diberikan oleh peneliti.

Informan dari keluarga tukang becak. Informan pertama bernama Hasan dari keluarga Suhariyanto ditemui dikediamannya jalan KH.Asyari No.24 Banyuwangi pada tanggal 30 Januari 2015 pukul 13.00 WIB. Informan kedua Ibu Tatik dari keluarga Suhairi, wawancara dilakukan pada tanggal 21 Januari 2015 pukul 11.00 WIB di rumah yang beralamatkan jalan PB Sudirman No.20 Banyuwangi. Informan ketiga Dika dari keluarga Harli pada tanggal 21 Januari 2015 pukul 13.00 WIB di jalan Andalas No. 43 Banyuwangi. Informan keempat bernama Jamila dari keluarga Djamari wawancara dilakukan di jalan Ikan Kembang Waru No. 41 Banyuwangi pada tanggal 22 Januari 2015 pukul 13.00 WIB. Informan kelima Dwi keluarga Indra dilakukan di jalan Riau No.23 Banyuwangi pada tanggal 23 Januari 2015 pukul 14.00 WIB. Informan keenam wawancara dilakukan pada tanggal 24 Januari 2015 pukul 13.00 WIB dengan Komariah keluarga dari Jayadi di jalan Samarinda No.2 Banyuwangi. Informan ketujuh bernama Sinta dari keluarga Budi, proses wawancara dilakukan pada tanggal 25 Januari 2015 pukul 15.00 WIB di jalan MT Haryono No.67 Banyuwangi. Informan kedelapan dilakukan pada tanggal 26 Januari 2015 pukul 14.00 WIB di jalan Katamso No.69 Banyuwangi dengan Ibu Titik keluarga dari Anam. Informan kesembilan bernama Ibu Sri dari keluarga Hendra, proses wawancara dilakukan pada tanggal 27 Januari 2015 pukul 14.00 WIB di jalan Imam Bonjol No.21 Banyuwangi. Informan kesepuluh yang beralamatkan di jalan Kepiting No. 53 Banyuwangi dengan Ibu Endang dari keluarga Iman pada tanggal 28 Januari 2015 pukul 14.00 WIB.

Informan dari Dinas Kebudayaan dan Pariwisata dengan Bapak Dariharto dilakukan pada tanggal 22 Januari 2015 pukul 08.45 WIB di kantor Dinas Kebudayaan dan Pariwisata. Informan dari tentor bernama Sibon dilakukan proses wawancara pada tanggal 29 Januari 2015 pukul 18.30 WIB di kantor (ELC) English Language Center.

\section{b. Reduksi Data (Data Reduction)}

Reduksi data dilakukan dalam penelitian ini dengan membuang jawaban dari salah satu informan yang dianggap tidak perlu. Jawaban dari salah satu informan yang bernama Bapak Budi mengatakan bahwa beliau mengikuti pelatihan tersebut karena diajak oleh teman-teman becak dan ingin mendapatkan uang lebih dari hari biasanya. Jawaban ini berbeda dengan jewaban dari informan lain, sehingga perlu adanya reduksi data. Mereduksi data berarti merangkum dan memfokuskan pada hal-hal yang penting dan membuang yang tidak perlu.

Berdasarkan hasil analisis data informan mengenai tanggapan adanya pelatihan Bahasa Inggris di Kota Banyuwangi karena seluruh informan mengatakan kegiatan utama mereka dengan pelatihan Bahasa Inggris adalah untuk belajar Bahasa Inggris dan menarik minat wisatawan asing.

\section{c. Penyajian Data (Data Display)}

Hasil wawancara yang dilakukan oleh informan pertama yang bernama Suhariyanto, menunjukkan respon positif adanya program pelatihan Bahasa Inggris di Kota Banyuwangi. Hal tersebut diuraikan dalam jawaban kedua terkait dengan adanya program pelatihan Bahasa Inggris di Kota Banyuwangi, informan ini menanggapi bahwa pelatihan Bahasa Inggris di Kota Banyuwangi berdampak positif karena mendapatkan ilmu yang sangat bermanfaat bagi tukang becak. Dengan adanya pelatihan tersebut tidak hanya bisa mengguidewisatawan asing, mengajak berbincang dan jalan-jalan menggunakan becak.

Hasil wawancara yang telah dilakukan oleh informan kedua yang bernama Suhairi dengan memberikan lima pertanyaan seperti yang dilakukan terhadap informan sebelumnya. Tanggapan informan kedua terkait dengan adanya pelatihan Bahasa Inggris bagi tukang becak di Kota Banyuwangi adalah merasa senang, karena telah diadakan pelatihan Bahasa Inggris. Hal tersebut diuraikan dalam jawaban ketiga terkait dengan tanggapan setelah mengikuti pelatihan Bahasa Inggris di Kota Banyuwangi, informan ini menanggapi bahwa setelah mengikuti pelatihan Bahasa Inggris ini sangat senang, karena dari yang tidak tahu sampai tahu Bahasa Inggris.

Hasil wawancara yang telah dilakukan oleh informan ketiga yang bernama Harli dengan memberi lima pertanyaan seperti yang dilakukan terhadap informan sebelumnya. Jawaban Bapak Harli terkait dengan adanya program pelatihan Bahasa Inggris di Kota Banyuwangi adalah bagus, karena tukang becak diberi perhatian khusus oleh pemerintah yang telah memfasilitasi untuk belajar Bahasa Inggris. Walaupun Harli mengikuti satu kali pertemuan saja dan menyuruh anaknya untuk mengikuti pelatihan tersebut karena gratis. Menurut Bapak Harli, anaknya masih sekolah pantasalah untuk anaknya yang sedang menuntu ilmu.

Hasil wawancara yang telah dilakukan oleh informan keempat yang bernama Djamari dengan memberi lima pertanyaan seperti yang dilakukan terhadap informan sebelumnya. Djamari memberikan tanggapannya terkait dengan adanya pelatihan Bahasa Inggris di Kota Banyuwangi tersebut sangatlah bagus karena kedepannya agar lebih banyak lagi wisatawan asing yang datang ke Banyuwangi. Menurut Djamari, pelatihan Bahasa Inggris ini selain meningkatkan pengetahuan, menarik minat wisatawan asing dan bisa menambah penghasilan bila ada wisatawan yang naik becak.

Hasil wawancara dengan informan kelima yang bernama Indra dengan memberikan lima pertanyaan seperti yang dilakukan terhadap informan sebelumnya. Menurut Indra, adanya pelatihan Bahasa Inggris di Kota Banyuwangi saat mengetahui menarik sekali dan kalau bisa sering-sering diadakan pelatihan Bahasa Inggris. Indra juga berpendapat walaupun baru sedikit tahu Bahasa Inggris setidaknya bisa untuk menambah penghasilan bagi keluarga di rumah.

Hasil wawancara dengan informan enam yang bernama Jayadi memberikan tangapan pertama terkait dengan adanya program pelatihan Bahasa Inggris di Kota Banyuwangi adalah agar bisa bergaul dengan turis-turis yang datang dari luar. Jayadi mempunyai tanggapan bisa lebih ngerti Bahasa inggris dan lebih pinter dari tukang becak yang belum 
mendapatkan pelatihan Bahasa Inggris. Uang yang didapatkan dari turis pun bisa ditabung untuk biaya sekolah anak.

Hasil wawancara dengan informan ketujuh yang bernama Budi terkait dengan adanya pelatihan Bahasa Inggris di Kota Banyuwangi adalah diajak teman-teman tukang becak, saat mengetahui pertama kali merasa kaget dan setuju-setuju saja karena Budi di ajak teman-teman tukang becak untuk mengikuti belajar Bahasa Inggris. Menurut Budi bermanfaat bisa mendapat ilmu baru seperti Bahasa Inggris dari guru yang mengajar dan mendapat uang lebih dari wisatawan asing.

Hasil wawancara dengan informan kedelapan yang bernama Anam dengan memberikan lima pertanyaan seperti yang dilakukan terhadap informan sebelumnya. Tanggapan Anam terkait dengan adanya pelatihan Bahasa Inggris di Kota Banyuwangi adalah antusias sekali untuk mengikuti pelatihan Bahasa Inggris ini. Berbeda dengan informan lainnya yang hanya menginginkan uang pengganti ngebecak, Anam mengungkapkan bahwa rezeki sudah ada yang ngatur jadi tidak perlu kawatir tertukar dengan yang lain. Anam menginginkan terus belajar Bahasa Inggris walaupun usia yang sudah tidak muda lagi tetapi masih semangat untuk belajar Bahasa Inggris. Budaya luar dan disiplin waktupun dipelajari Bapak Anam supaya tidak mengecewakan para penumpangnya seperti wisatawan asing. Keluargapun turut senang dengan adanya pelatihan Bahasa Inggris tersebut karena Anam menjadi peserta pelatihan Bahasa Inggris.

Hasil wawancara dengan informan kesembilan yang bernama Hendra tentang pelatihan Bahasa Inggris di Kota Banyuwangi yaitu merasa aneh karena tukang becak di suruh belajar Bahasa Inggris dengan maksud dan tujuannya untuk menambah wawasan dan pengetahuan Bahasa Inggris bagi tukang becak agar banyak wisatawan asing yang berkunjung ke Kota Banyuwangi. Setelah mengikuti pelatihan Hendra mengungkapkan bahwa seru sekali belajar Bahasa Inggris bersama teman-teman becak yang lain dan bisa langsung praktek pada wisatawan asing yang akan naik becak dengan kemampuan Bahasa Inggris yang sudah dipelajari.

Hasil wawancara dengan informan kesepuluh yang bernama Iman terkait dengan adanya pelatihan Bahasa Inggris di Kota Banyuwangi yaitu menarik sekali tetapi Iman khawatir merasa seperti disekolahkan lagi dengan usia yang sudah tidak muda tetapi setelah belajar dengan tentor yang ramah Bapak Iman tidak kawatir ternyata kami yang tukang becak juga bisa belajar Bahasa Inggris. Iman mengungkapkan setelah mengikuti pelatihan langsung praktek kepada wisatawan asing dan mengajak berkeliling pasar, taman dan sambil bekomunikasi dengan Bahasa Inggris yang sudah dikuasai.

Hasil wawancara kepada keluarga dari tukang becak, hampir seluruh informan mengatakan bahwa para tukang becak yang menjadi informan mengikuti pelatihan Bahasa Inggris tersebut. Semua keluarga merasa senang dan bangga karena para tukang becak bisa menambah penghasilan, penumpangnya wisatawan asing dan berbagi cerita tentang prlaku wisatawan asing. Ada sebagian informan menyuruh anaknya untuk mengikuti pelatihan Bahasa Inggris dan mendapatkan uang lebih dari bapak tukang becak.
Hasil wawancara dengan informan bernama Bapak Dariharto terkait dengan maksud dan tujuan diadakan pelatihan Bahasa Inggris bagi tukang becak adalah untuk peningkatan pelayanan pariwisata di Banyuwangi dengan memberikan keterampilan atau pengetahuan tentang Bahasa Inggris.Selain itu, Bapak Dariharto memberikan6 alasan diadakannya pelatihan tersebut karena merupakan kebutuhan, Banyuwangi sering mengadakan city tour terkadang dari hotel maupun dari Dinas Pariwisata itu sendiri untuk lebih mengenal Kota Banyuwangi.Jadi, tukang becak tidak hanya mengantar tetapi juga sambil berkomuikasi Bahasa Inggris yang dikuasai.

Hasil wawancara dengan informan bernama Bapak Sibon terkait dengan respon para peserta pelatihan adalah awalnya para tukang becak khawatir. Mereka befikir bisa tidak mereka belajar Bahasa Inggris dan mereka tidak suka dengan Bahasa Inggris. Kalau tidak suka bagaimana mau bisa, dengan begitu bapak Sibon mengajar dan mengubah pola pikir tukang becak agar mereka suka dan bisa Bahasa Inggris. Selain itu, pendapat Bapak Sibon tentang peserta pelatihan Bahasa Inggris dengan berbagai kemampuan ada yang tidak bisa baca tulis dan cara mengajarnya dengan hafalan saja yang tukang becak butuhkan dilapangan. Tidak hanya Bahasa Inggris tetapi Budaya sopan santun pun dipelajari untuk memoderator wisatawan asing.

\section{d. Penarikan Kesimpulan (Conclusions)}

Kesimpulan dari hasil uraian wawancara adalah respon positif dan respon negatif tukang becak terhadap pelatihan Bahasa Inggris yang dilaksanakan Pemkab Banyuwangi dalam menunjang keberhasilan wisata. Pemahaman tukang becak terhadap maksud dan tujuannya diadakan pelatihan Bahasa Inggris yang dilaksanakan Pemkab Banyuwangi dalam menunjang keberhasilan wisata.

\section{Pembahasan}

\section{Respon}

Hasil dari wawancara dengan seluruh informan yakni terkait dengan pelatihan Bahasa Inggris di Kota Banyuwangi yang berjumlah 22 orang yang terbagi dalam golongan tukang becak, keluarga dari tukang becak, Dinas Kebudayaan dan Pariwisata, dan Tentor. Pertama, informan dari tukang becak, tanggapan positif tukang becak adalah membuat para tukang becak mendapatkan ilmu tentang kebudayaan khususnya kebudayaan atau obyek wisata yang ada di Banyuwangi serta mendapatkan ilmu tentang bagaimana cara berkomunikasi berbahasa Inggris dengan para wisatawan asing. Tanggapan negatif beberapa tukang becak yang berpendapat bahwa pelatihan Bahasa Inggris tersebut sangat berat dikarenakan lebih memilih mencari penghasilan untuk keluarga, terdapat tukang becak yang hanya mengikuti satu kali pertemuan saja karena direkomendasikan oleh sesama tukang becak, beberapa tukang becak yang kurang mengikuti pelatihan Bahasa Inggris dikarenakan usia yang bisa dibilang sudah tua diatas 60 tahun keatas, dan untuk menghafalkan kosakata Bahasa Inggris sangatlah sulit dikarenakan baru belajar Bahasa Inggris.

Kedua informan yang berasal dari keluarga didapat penjelasan bahwa pihak keluarga sangat senang dan mendukung program pelatihan Bahasa Inggris untuk para tukang becak. Sebagai kepala keluarga, setelah mengikuti pelatihan Bahasa Inggris mampu mengajarkan Bahasa Inggris 
pada keluarga terutama anak yang masih usia dini. Pihak keluarga bangga dan senang, melihat bapak atau para tukang becak bisa berkomunikasi Bahasa Inggris. Pelatihan Bahasa Inggris yang gratis memberikan manfaat yang besar bagi keluarga, karena penghasilan menjadi meningkat dengan tumpangan para turis atau wisatawan asing dibandingkan dengan tumpangan wisatawan lokal. Serta lebih mengetahui kebudayaan Banyuwangi lebih dalam.

Ketiga informan yang berasal dari Dinas Kebudayan dan Pariwisata diperoleh maksud dan tujuan diadakan pelatihan Bahasa Inggris bagi tukang becak adalah peningkatan pelayanan pariwisata di Banyuwangi dengan memberi keterampilan atau pengetahuan tentang Bahasa Inggris. Agar mereka bisa berkomunikasi dengan wisatawan mancanegara. Fasilitas yang tersedia seperti memberikan makanan, buku pelajaran bahasa inggris, serta uang pengganti ongkos angkut sebesar Rp 75.000,-/ hari, membuat para tukang becak tertarik mengikuti pelatihan bahasa inggris. Selain itu pelatihan ini juga dilakukan secara gratis. Ilmu tentang kebudayaan kota Banywangi pun diajarkan pula dalam pelatihan ini, sehingga jika para turis ingin mengetahui salah satu obyek wisata, tukang becak yang telah diajarkan oleh para tentor dapat menjawabnya dengan benar.

Keempat informan berasal dari tentor dengan respon dari peserta pelatihan Bahasa Inggris adalah awalnya para tukang becak merasa khawatir dan mereka pasti berfikir bisa tidak mereka belajar Bahasa Inggris. Namun, setelah berlangsung kegiatan bahasa inggris, para tukang becak bisa memahami dan mengerti apa yang diajarkan oleh para tentor. Para tentorpun, bangga melihat semangat dari para tukang becak dalam mengikutri program ini.

\section{Pemahaman}

Sebagian tukang becak yang paham maksud dan tujuan diadakan pelatihan Bahasa Inggris di peroleh bahwa mereka memahami wisatawan lokal dan asing, memahami makna dari ucapan para turis, saling berinteraksi dan komunikasi dengan wisatawan asing, paham tentang pelajaran Bahasa Inggris, pemahaman untuk mengenalkan tempat wisata yang ada di Banyuwangi, mengenal budaya luar seperti apa, dan yang tidak kalah pentingnya pemahaman untuk menarik minat wisatawan asing yang berkunjung dan melancong di Kota Banyuwangi dengan menggunakan Bahasa Inggris. Ada pula tukang becak yang belum memahami dengan maksud dan tujuan karena pemahamannya tidak sesuai dengan Dinas Kebudayaan dan Pariwisata yang hanya ikut-ikutan saja dengan alasan untuk mendapatkan uang yang banyak dari wisatawan asing yang sedang berwisata di Kota Banyuwangi. Tukang becak memanfaat kan peluang ini untuk mendapatkan uang dari wisatawan.

\section{Simpulan}

Respon tukang becak terhadap pelatihan Bahasa Inggris ada yang positif dan negatif. Respon positif tukang becak adalah membuat para tukang becak mendapatkan ilmu tentang kebudayaan khususnya kebudayaan atau obyek wisata yang ada di Banyuwangi serta mendapatkan ilmu tentang bagaimana cara berkomunikasi berbahasa Inggris dengan para wisatawan asing. Respon negatif, beberapa tukang becak berpendapat bahwa pelatihan Bahasa Inggris tersebut sangat berat, terdapat tukang becak yang hanya mengikuti satu kali pertemuan saja, beberapa tukang becak yang kurang mengikuti pelatihan Bahasa Inggris dikarenakan usia yang bisa dibilang sudah tua, dan untuk menghafalkan kosakata Bahasa Inggris sangatlah sulit. Selain respon positif dan negatif terdapat manfaat yang diperoleh dari pelatihan Bahasa Ingris tersebut. Tukang becak mendapatkan manfaat yang banyak dari pelatihan Bahasa Inggris terutama yang mengikuti pelatihan tersebut untuk meningkatkan penghasilan dan manfaanya tidak hanya untuk sekarang tetapi juga untuk masa depan. Ada juga yang menyuruh putranya yang mengikuti pelatihan dan manfaatnya akan dirasakan oleh putranya tersebut, dalam hal ini tukang becak yang menyuruh putranya yang mengikuti pelatihan menganggap bahwa akan mengurangi penghasilan bila ikut serta pelatihan hal ini karena hanya melihat jangka pendek.

Pemahaman tukang becak terhadap pelatihan Bahasa Inggris ada yang paham dan tidak paham. Sebagian tukang becak yang paham maksud dan tujuan diadakan pelatihan Bahasa Inggris diperoleh bahwa tukang becak memahami wisatawan lokal dan asing, memahami makna dari ucapan para turis, saling berinteraksi dan komunikasi dengan wisatawan asing, paham tentang pelajaran Bahasa Inggris, pemahaman untuk mengenalkan tempat wisata yang ada di Banyuwangi, mengenal budaya luar seperti apa, pemahaman untuk menarik minat wisatawan asing yang berkunjung dan melancong di Kota Banyuwangi dengan menggunakan Bahasa Inggris, dan menjadi tukang becak sadar wisata.Sebagian tukang becak yang belum memahami dengan maksud dan tujuan karena pemahamannya tidak sesuai dengan Dinas Kebudayaan dan Pariwisata yang hanya ikut-ikutan saja dengan alasan untuk mendapatkan uang yang banyak dari wisatawan asing yang sedang berwisata di Kota Banyuwangi. Kemampuan tukang becak dalam berkomunikasi menggunakan Bahasa Inggris akan berpengaruh terhadap kenyamanan wisatawan asing yang datang berkunjung ke Kota Banyuwangi.

\section{Ucapan Terima Kasih}

Penulis mengucapkan terimakasih kepada semua informan dalam penelitian ini yang telah meluangkan waktu untuk proses wawancara sehingga data atau informasi yang diharapkan peneliti diperoleh.

\section{Referensi}

Burhan Bungin. 2003. Analisis Data Kualitatif. Jakarta: Rajawaji Pers.

Mukhtar. 2013. Metode Praktis Penelitian Deskriptif Kualutatif. Jakarta Selatan: Referensi (GP Press Group).

Sugiyono. 2014.Memahami Penelitian Kualitatif. Bandung: cv, Alfabeta 